\title{
Comparison between Two Different Snubbers of a Boost Converter for Achieving Soft-switching Features
}

\author{
Cheng-Tao Tsai, ${ }^{1 *}$ Yan-Wei Huang, ${ }^{1}$ and Tsair-Chun Liang ${ }^{2}$ \\ ${ }^{1}$ Department of Electrical Engineering, National Chin-Yi University of Technology, Taichung 41170, Taiwan \\ ${ }^{2}$ Department of Electronic Engineering, National Kaohsiung University of Science and Technology, \\ Kaohsiung 824005, Taiwan
}

(Received March 23, 2021; accepted June 10, 2021)

Keywords: snubbers, soft switching, electromagnetic interference (EMI)

This paper presents a comparison between two different snubbers of a boost converter for achieving soft-switching features. To obtain high current capability and high conversion efficiency, a boost converter is operated in a hard-switching mode, which will induce high component stresses, high switching losses of active switches, and serious electromagnetic interference (EMI). To overcome these disadvantages, two different snubbers using simple passive components that are incorporated in boost converters are compared. The two different snubbers are a buck snubber and a boost snubber. In this study, the performance and efficiency of boost converters with the buck snubber and with the boost snubber are obtained. From the characteristic analyses and experimental results, it has been verified that the boost converter with the boost snubber achieved lower component stresses, lower switching losses of active switches and higher conversion efficiency than the boost converter with the buck snubber.

\section{Introduction}

Green energies include photovoltaic (PV), wind, and geothermal energy, which have the features of cleanliness, freedom from maintenance, and abundance. Currently, PV panels are one of the most widely applied green energies. ${ }^{(1,2)}$ To maximize the power of PV panels, the maximum power point tracking method is incorporated in a microchip. However, the output power of PV panels is unstable and has a low output voltage. Therefore, PV panels require a boost converter to stabilize the output power and boost voltage. ${ }^{(3-6)}$ A boost converter is operated in a hard-switching mode, which induces serious stresses and switching losses of active switches. ${ }^{(7-10)}$ These disadvantages lead to low transfer efficiency and serious electromagnetic interference (EMI) of the boost converter. ${ }^{(11-14)}$

To overcome these disadvantages, a converter with an inductor-capacitor-diode (LCD) snubber that was first reported in 2009 is shown in Fig. 1. ${ }^{(15)}$ Although the boost converter with the LCD snubber can decrease component stresses and switching losses of active switches, it still has high EMI and low transfer efficiency. ${ }^{(16-20)}$ In previous studies, a boost converter with a

*Corresponding author: e-mail: cttsai@ncut.edu.tw https://doi.org/10.18494/SAM.2021.3393 


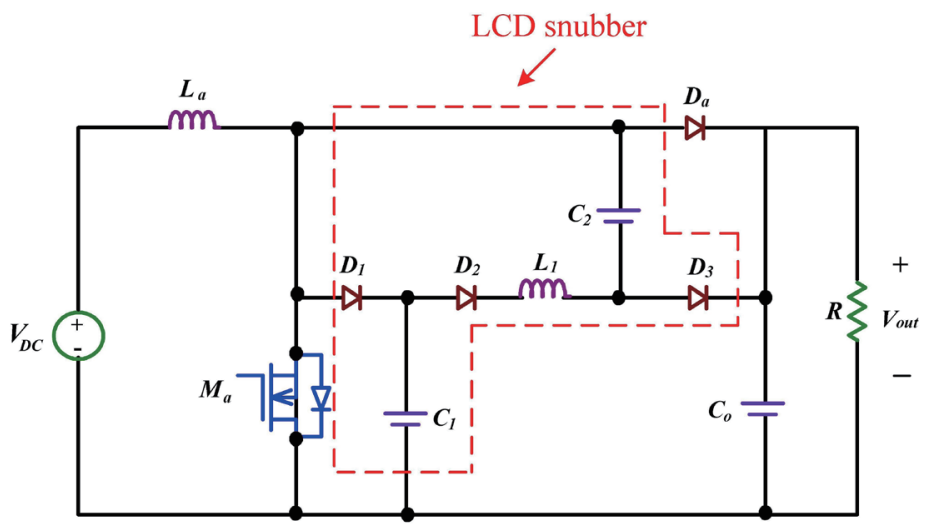

Fig. 1. (Color online) Structure of the boost converter with an LCD snubber.

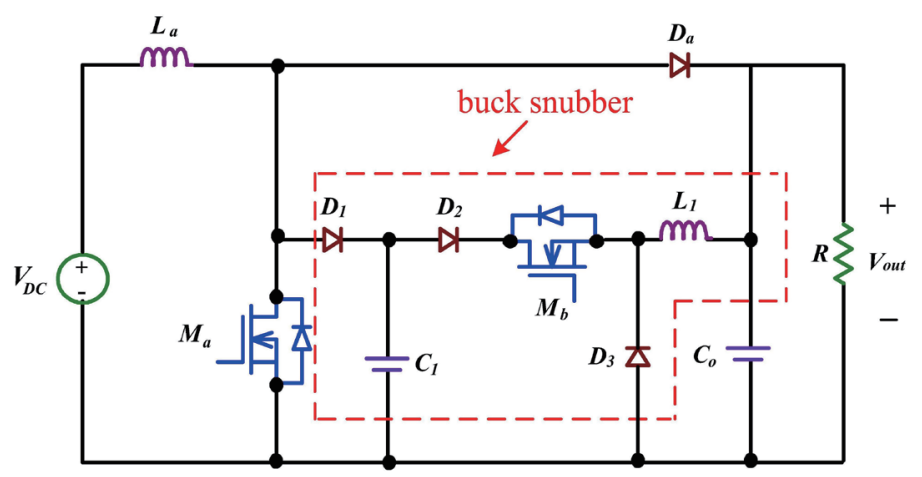

Fig. 2. (Color online) Structure of the boost converter with a buck snubber.

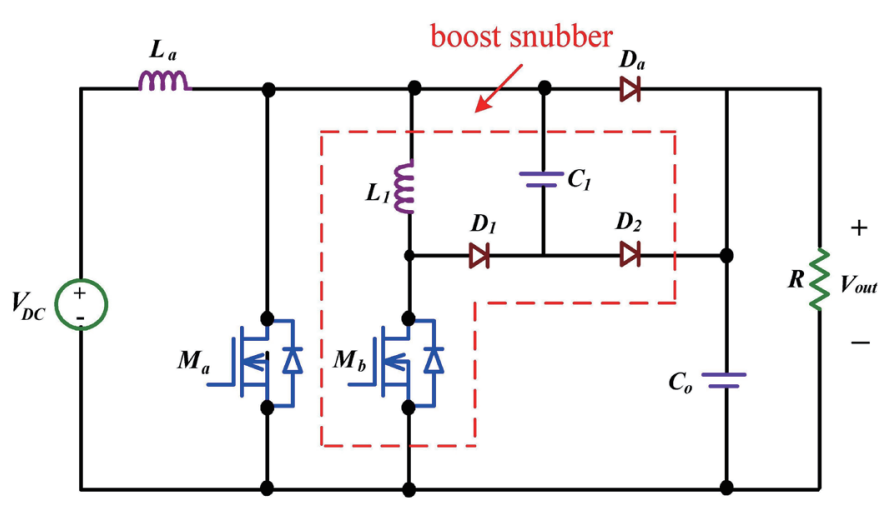

Fig. 3. (Color online) Structure of the boost converter with a boost snubber.

buck snubber or a boost snubber was proposed to alleviate the drawbacks of the boost converter with an LCD snubber, as shown in Figs. 2 and 3. The structures of the boost converters with the buck snubber and with the boost snubber are analyzed in Sect. 2. The design considerations, experimental results, and efficiency of the boost converters with the buck snubber and with the boost snubber are compared in Sects. 3 and 4. Finally, a conclusion is given in Sect. 5. 


\section{Structure Analyses of Boost Converters with a Buck Snubber and with a Boost Snubber}

Figure 2 shows the structure of the boost converter with a buck snubber for achieving softswitching functions. The buck snubber consists of an active switch $\left(M_{b}\right)$, a resonant capacitor $\left(C_{1}\right)$, a resonant inductor $\left(L_{1}\right)$, and three diodes $\left(D_{1}, D_{2}\right.$, and $\left.D_{3}\right)$. The operational methods of the boost converter with a buck snubber can be separated into four modes, concisely explained as follows:

\section{[Mode 1]}

When the main switch $\left(M_{a}\right)$ and the auxiliary switch $\left(M_{b}\right)$ are turned on at the same interval, the main inductor $\left(L_{a}\right)$ is charged and the main current $i_{L a}$ flowing through the path $V_{D C} \rightarrow L_{a} \rightarrow$ $M_{a}$ is linearly increased. Simultaneously, the auxiliary inductor $\left(L_{1}\right)$ is also charged by the capacitor $\left(C_{1}\right)$. The current $i_{L 1}$ of the auxiliary inductor $\left(L_{1}\right)$ flowing through the path $C_{1} \rightarrow D_{2}$ $\rightarrow M_{b} \rightarrow L_{1} \rightarrow R$ is linearly increased. In this interval, the main switch $\left(M_{a}\right)$ is turned on under a hard-switching condition. Therefore, the main switch $\left(M_{a}\right)$ induces serious switching losses. The equivalent circuit is shown in Fig. 4(a).

\section{[Mode 2]}

In this interval, when the voltage $V_{c 1}$ of the capacitor $\left(C_{1}\right)$ is dropped to zero, the auxiliary switch $\left(M_{b}\right)$ is turned off under a zero-voltage transient (ZVT) condition to implement a soft-

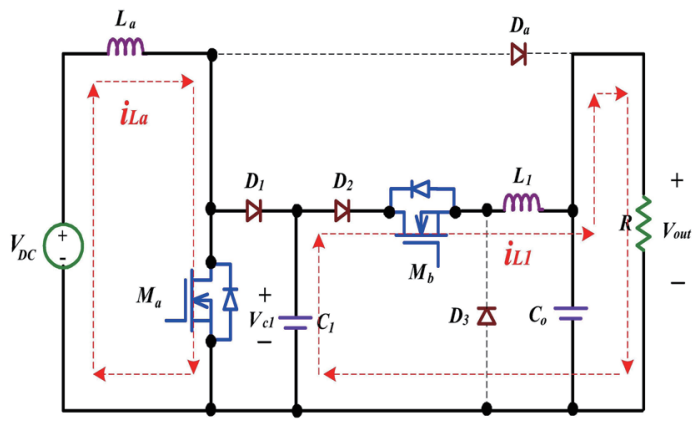

(a)

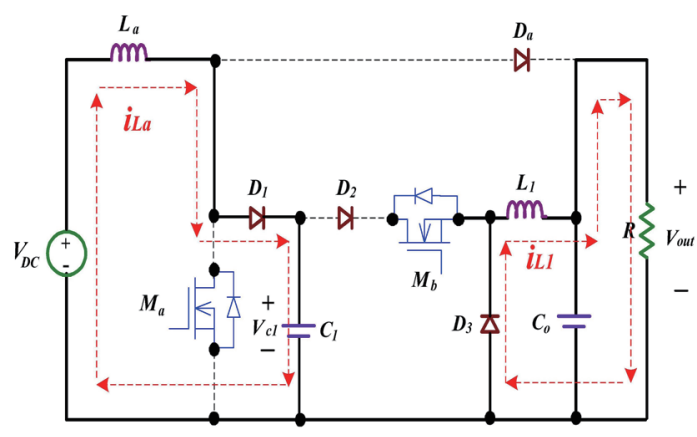

(c)

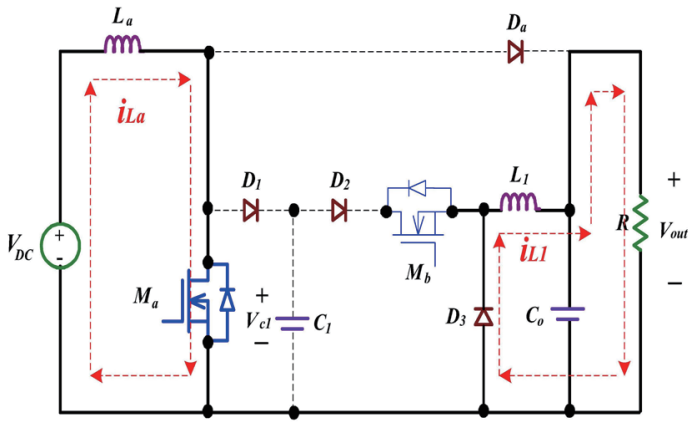

(b)

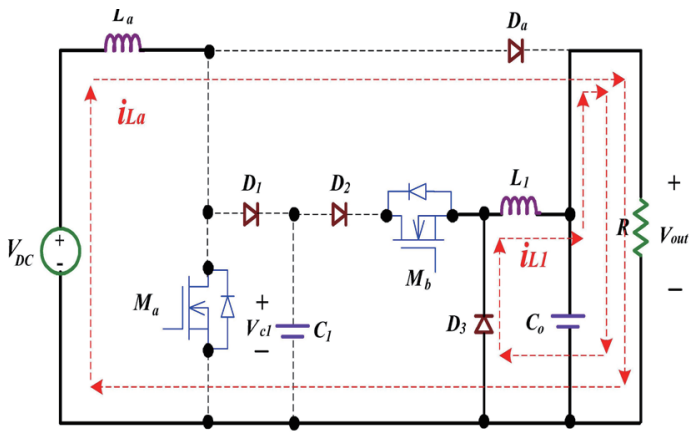

(d)

Fig. 4. (Color online) Equivalent circuit modes of boost converter with a buck snubber. (a) Mode 1, (b) Mode 2, (c) Mode 3, and (d) Mode 4. 
switching feature. At this time, the main switch $\left(M_{a}\right)$ is continuously turned on and the auxiliary current $i_{L 1}$ flows through the path of $D_{3} \rightarrow L_{1} \rightarrow R$. The equivalent circuit is shown in Fig. 4(b).

[Mode 3]

In this interval, the auxiliary switch $\left(M_{b}\right)$ is kept turned off. At this time, the main switch $\left(M_{a}\right)$ is turned off under a ZVT condition to implement a soft-switching feature. The current $i_{L a}$ of the main inductor $\left(L_{a}\right)$ flows through the path $V_{D C} \rightarrow L_{a} \rightarrow D_{1} \rightarrow C_{1}$, and the current $i_{L 1}$ of the auxiliary inductor $\left(L_{1}\right)$ continuously flows through the path $D_{3} \rightarrow L_{1} \rightarrow R$. The equivalent circuit is shown in Fig. 4(c).

\section{[Mode 4]}

In this interval, when the voltage of the capacitor $\left(C_{1}\right)$ is charged to $V_{c 1}$, the diode $\left(D_{1}\right)$ is turned off. The current $i_{L a}$ of the main inductor $\left(L_{a}\right)$ flowing through the path $V_{D C} \rightarrow L_{a} \rightarrow D_{a}$ $\rightarrow R$ is linearly decreased. The operation of the boost converter with a buck snubber over one switching cycle is completed, and the equivalent circuit is shown in Fig. 4(d).

Figure 3 shows the structure of the boost converter with a boost snubber for achieving softswitching functions. The boost snubber consists of an active switch $\left(M_{b}\right)$, a resonant capacitor $\left(C_{1}\right)$, a resonant inductor $\left(L_{1}\right)$, and three diodes $\left(D_{1}, D_{2}\right.$, and $\left.D_{3}\right)$. The operational modes of the boost converter with a buck snubber can be separated into eight modes, concisely explained as follows:

\section{[Mode 1]}

When the main switch $\left(M_{a}\right)$ is turned on and the auxiliary switch $\left(M_{b}\right)$ is turned off in the same interval, the main inductor $\left(L_{a}\right)$ is charged and the main current $i_{L a}$ flowing through the path $V_{s} \rightarrow L_{a} \rightarrow M_{a}$ is linearly increased. Simultaneously, the capacitor $\left(C_{o}\right)$ delivers power to load $(R)$. The equivalent circuit is shown in Fig. 5(a).

\section{[Mode 2]}

In this interval, the main switch $\left(M_{a}\right)$ is turned off, and the auxiliary switch $\left(M_{b}\right)$ is kept off. The diode $\left(D_{a}\right)$ is turned on and the current $i_{L a}$ of the main inductor $\left(L_{a}\right)$ flowing through the path $V_{s} \rightarrow L_{a} \rightarrow D_{a} \rightarrow R$ is linearly decreased. The equivalent circuit is shown in Fig. 5(b).

\section{[Mode 3]}

In this interval, the main switch $\left(M_{a}\right)$ is kept off, and the auxiliary switch $\left(M_{b}\right)$ is turned on. The current $i_{L a}$ of the main inductor $\left(L_{a}\right)$ is divided into two current paths $i_{L 1}$ and $i_{D 1}$, namely, $V_{s}$ $\rightarrow L_{a} \rightarrow L_{1} \rightarrow M_{b}$ and $V_{s} \rightarrow L_{a} \rightarrow D_{a} \rightarrow R$. The equivalent circuit is shown in Fig. 5(c).

\section{[Mode 4]}

In this interval, when the main current $i_{L a}$ is equal to the auxiliary current $i_{L 1}$, the diode $\left(D_{a}\right)$ is turned off. Simultaneously, the capacitor $\left(C_{o}\right)$ delivers power to load $(R)$. The equivalent circuit is shown in Fig. 5(d).

\section{[Mode 5]}

In this interval, when the main current $i_{L a}$ is less than the auxiliary current $i_{L 1}$, the body diode of the main switch $\left(M_{a}\right)$ is turned on, creating a ZVS condition for the main switch $\left(M_{a}\right)$. Simultaneously, the capacitor $\left(C_{o}\right)$ continuously delivers power to load $(R)$. The equivalent circuit is shown in Fig. 5(e). 


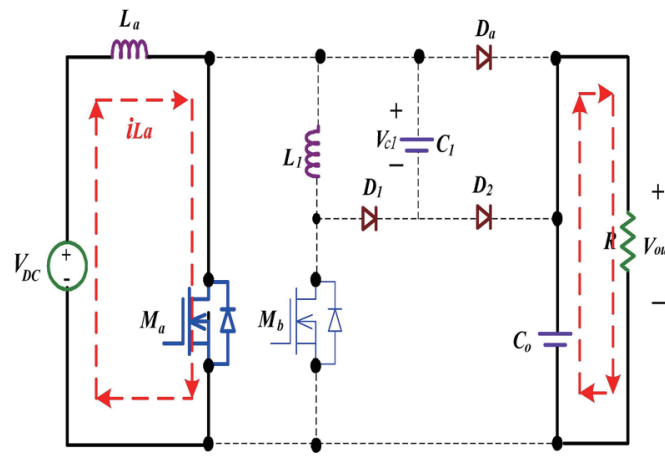

(a)

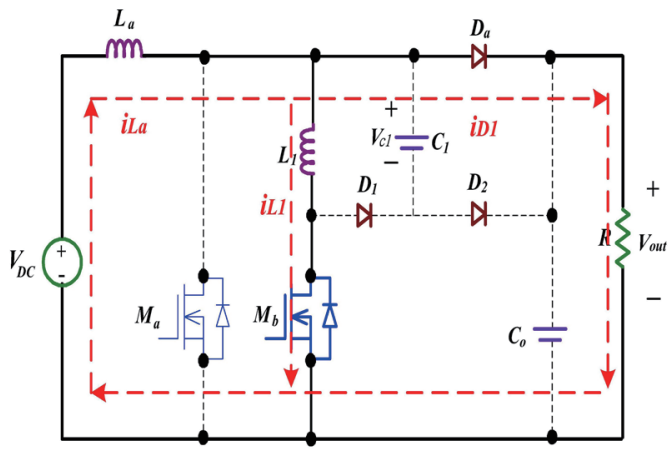

(c)

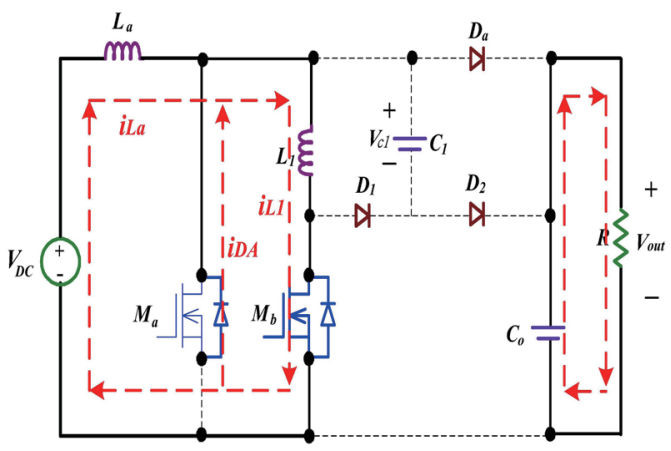

(e)

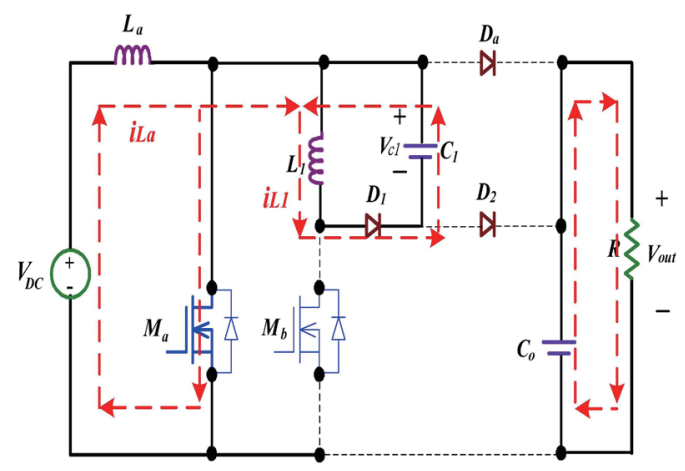

(g)

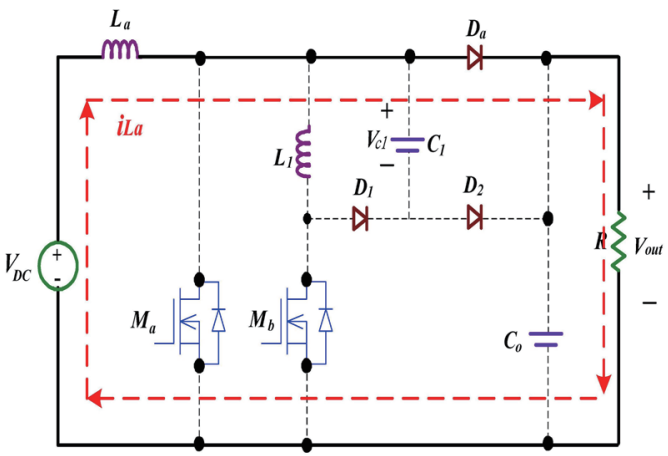

(b)

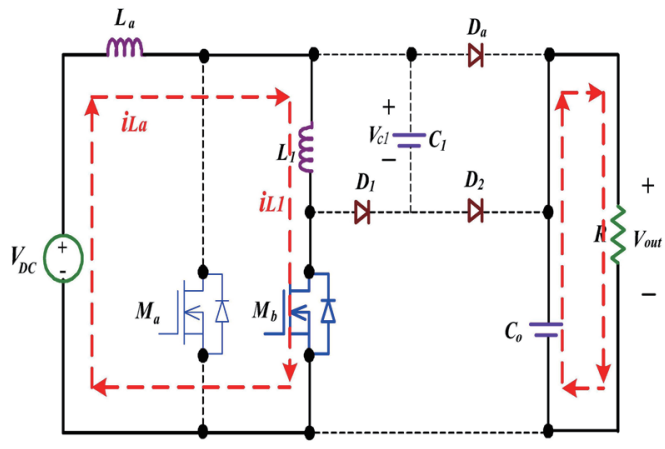

(d)

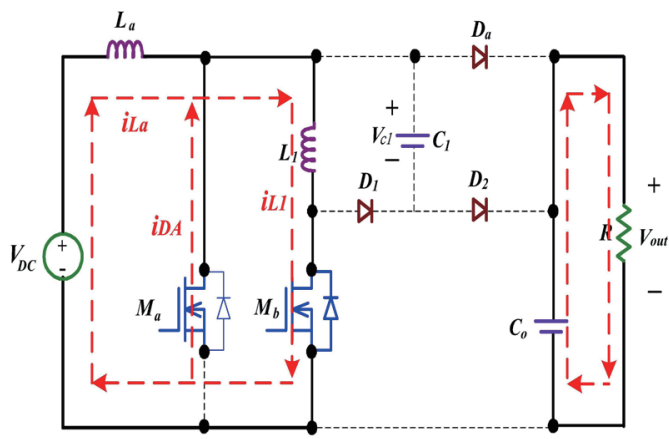

(f)

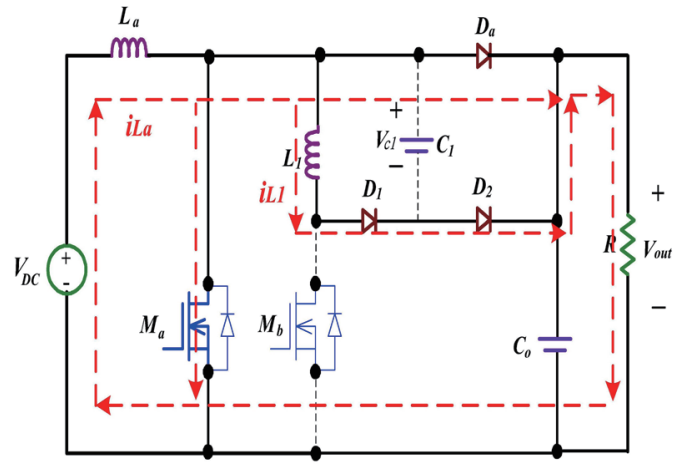

(h)

Fig. 5. (Color online) Equivalent circuit modes of boost converter with a boost snubber. (a) Mode 1, (b) Mode 2, (c) Mode 3, (d) Mode 4, (e) Mode 5, (f), Mode 6, (g) Mode 7, and (h) Mode 8. 


\section{[Mode 6]}

In this interval, the main switch $\left(M_{a}\right)$ is turned on and the auxiliary switch $\left(M_{b}\right)$ is kept on. The current $i_{L a}$ of the main inductor $\left(L_{a}\right)$ is divided into two current paths $i_{L 1}$ and $i_{M a}$, namely, $V_{s}$ $\rightarrow L_{a} \rightarrow M_{a}$ and $V_{s} \rightarrow L_{a} \rightarrow L_{1} \rightarrow M_{b}$. Simultaneously, the capacitor $\left(C_{o}\right)$ delivers power to load $(R)$. The equivalent circuit is shown in Fig. 5(f).

\section{[Mode 7]}

In this interval, the main switch $\left(M_{a}\right)$ is kept on and the auxiliary switch $\left(M_{b}\right)$ is turned off. The current $i_{L 1}$ of the auxiliary inductor $\left(L_{1}\right)$ is transferred to the capacitor $\left(C_{1}\right)$, and the diode $\left(D_{1}\right)$ is turned on. The current $i_{L 1}$ of the auxiliary inductor $\left(L_{1}\right)$ flows through the path $L_{1} \rightarrow D_{1}$ $\rightarrow C_{1}$. Simultaneously, the capacitor $\left(C_{o}\right)$ continuously delivers power to load $(R)$. The equivalent circuit is shown in Fig. 5(g).

\section{[Mode 8]}

In this interval, when the voltage $V_{c 1}$ of the capacitor $\left(C_{1}\right)$ is dropped to zero, the diodes $\left(D_{2}\right.$ and $\left.D_{a}\right)$ are turned on. The current $i_{L a}$ of the main inductor $\left(L_{a}\right)$ is divided into three current paths $i_{M a}, i_{L 1}$, and $i_{D a}$, namely, $V_{s} \rightarrow L_{a} \rightarrow M_{a}, V_{s} \rightarrow L_{a} \rightarrow L_{1} \rightarrow D_{1} \rightarrow D_{2} \rightarrow R$, and $V_{s} \rightarrow L_{a} \rightarrow$ $D_{a} \rightarrow R$. The operation of the boost converter with a boost snubber over one switching cycle is completed. The equivalent circuit is shown in Fig. 5(h).

\section{Design Considerations of Boost Converters with a Buck Snubber and with a Boost Snubber}

This section presents the design considerations of the boost converters with a buck snubber and with a boost snubber. The design considerations are divided into two parts: the first part is the boost converter with a buck snubber and the second part is the boost converter with a buck snubber. The design considerations of their key components are depicted as follows:

\section{A) Selection of Main Switch $\left(M_{a}\right)$ and Auxiliary Switch $\left(M_{b}\right)$}

In Figs. 2 and 3, the main switch $\left(M_{a}\right)$ and auxiliary switch $\left(M_{b}\right)$ use metal-oxidesemiconductor field-effect transistors (MOSFETs). The consideration of the MOSFETs involves their conduction losses and voltage stresses. Therefore, MOSFETs with low channel resistance $R_{d s(o n)}$ are adopted because they can usually keep conduction losses low. In this application, the IRFP450 MOSFETs with a drain-source breakdown voltage of $500 \mathrm{~V}$ and a channel resistance $R_{d s(o n)}$ of $0.4 \Omega$ are selected for use.

\section{B) Selection of Main Inductor $\left(L_{a}\right)$}

In Fig. 2, the operated current of the main inductor $\left(L_{a}\right)$ of the boost converter with a buck snubber is designed with a continuous-conduction mode (CCM), in which the design condition is

$$
L_{a}=\frac{V_{o u t} T_{s}}{2 I_{o B}} D(1-D)^{2}
$$

where $V_{\text {out }}$ is the output voltage of the boost converter with a buck snubber, $T_{S}$ is the switching period of the main switch $\left(M_{a}\right), I_{o B}$ is the boundary output current of the main inductor $\left(L_{a}\right)$, and $D$ is the duty ratio of the main switch $\left(M_{a}\right)$. 
In Fig. 3, the operated current of the main inductor $\left(L_{a}\right)$ of the boost converter with a boost snubber is designed with a CCM, in which the design condition is

$$
L_{a}=\frac{V_{\text {out }}^{2} T_{s}}{2 P_{\text {out }}}\left(1-\frac{V_{\text {out }}}{V_{s}}\right)
$$

where $V_{s}$ is the voltage and $P_{\text {out }}$ is the output power of the boost converter with a boost snubber.

\section{C) Selection of Output Filter Capacitor $\left(C_{o}\right)$}

In Figs. 2 and 3, the output filter capacitor $\left(C_{o}\right)$ is selected to buffer the output voltages, suppress spikes, and filter ripples of the boost converter. Three $470 \mu \mathrm{F}$ electrolytic capacitors in parallel are selected.

\section{Experimental Results}

To compare the performances of the boost converter with a buck snubber and with a boost snubber, two prototypes are built with the following specifications:

- input voltage: $V_{s}=156 \mathrm{~V}_{\mathrm{DC}}$,

- output voltage: $V_{o}=400 \mathrm{~V}_{\mathrm{DC}}$,

- output current: $I_{o}=1 \mathrm{~A}$,

- output power: $P_{\text {out }}=400 \mathrm{~W}$, and

- switching frequency of active switches: $f=50 \mathrm{kHz}$.

The experimental results of the boost converter with an LCD snubber, the boost converter with a buck snubber, and the boost converter with a boost snubber are described in this section. Figure 6 shows the voltage waveforms of the main switch $\left(M_{a}\right)$ of the boost converter with an LCD snubber. It can be seen that the main switch $\left(M_{a}\right)$ has a hard-switching feature and highpeak-current stresses at the turn-on transient and a ZVT switching feature and high-peak-voltage stresses at the turn-off transient. Figure 7 shows the voltage waveforms of the main switch $\left(M_{a}\right)$

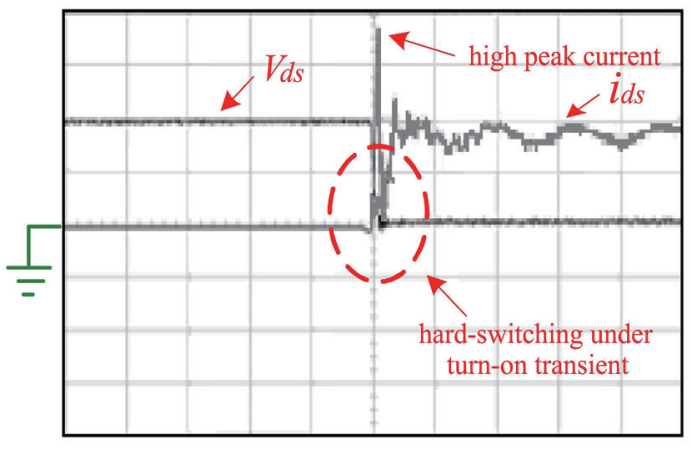

(a)

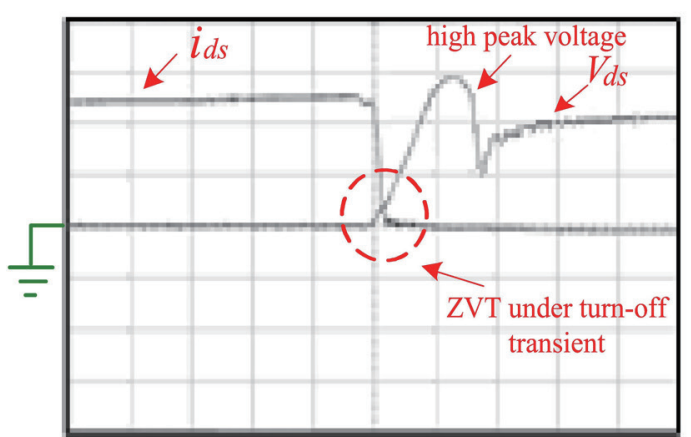

(b)

Fig. 6. (Color online) Measured voltage and current waveforms of main switch $\left(M_{a}\right)$ of the boost converter with an LCD snubber: (a) operated at turn-on transient $\left(V_{d s(M a)}: 200 \mathrm{~V} / \mathrm{div}, i_{d s(M a)}: 1 \mathrm{~A} / \mathrm{div}\right.$, time: $\left.0.5 \mu \mathrm{s} / \mathrm{div}\right)$ and (b) operated at turn-off transient $\left(V_{d s(M a)}: 200 \mathrm{~V} / \mathrm{div}, i_{d s(M a)}: 1 \mathrm{~A} / \mathrm{div}\right.$, time: $\left.0.5 \mu \mathrm{s} / \mathrm{div}\right)$. 


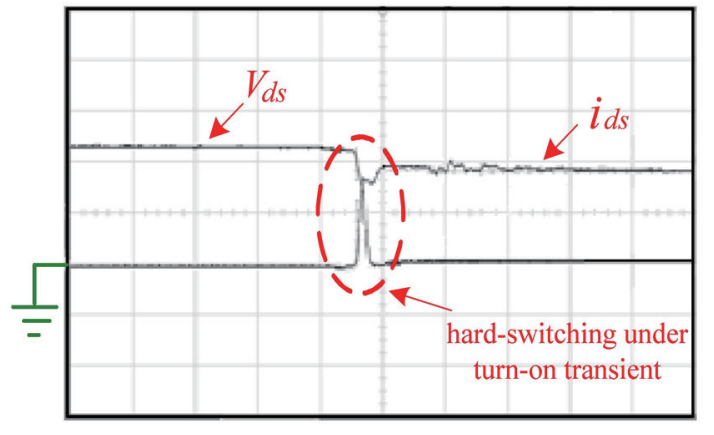

(a)

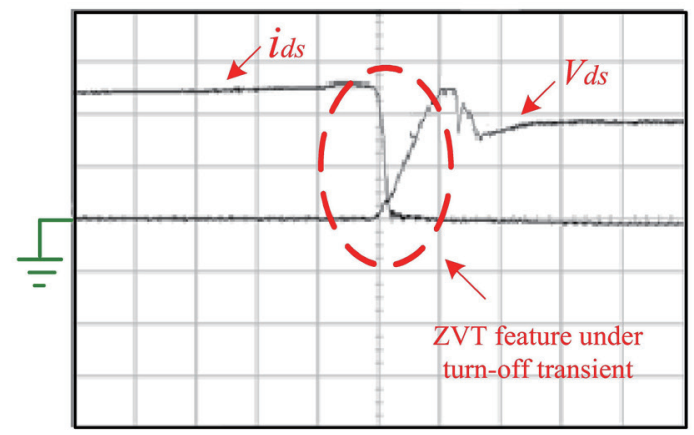

(b)

Fig. 7. (Color online) Measured voltage and current waveforms of main switch $\left(M_{a}\right)$ of the boost converter with a buck snubber: (a) operated at turn-on transient $\left(V_{d s(M a)}: 200 \mathrm{~V} / \mathrm{div}, i_{d s(M a)}: 1 \mathrm{~A} / \mathrm{div}\right.$, time: $\left.0.5 \mu \mathrm{s} / \mathrm{div}\right)$ and (b) operated at turn-off transient $\left(V_{d s(M a)}: 200 \mathrm{~V} / \mathrm{div}, i_{d s(M a)}: 1 \mathrm{~A} /\right.$ div, time: $\left.0.5 \mu \mathrm{s} / \mathrm{div}\right)$.

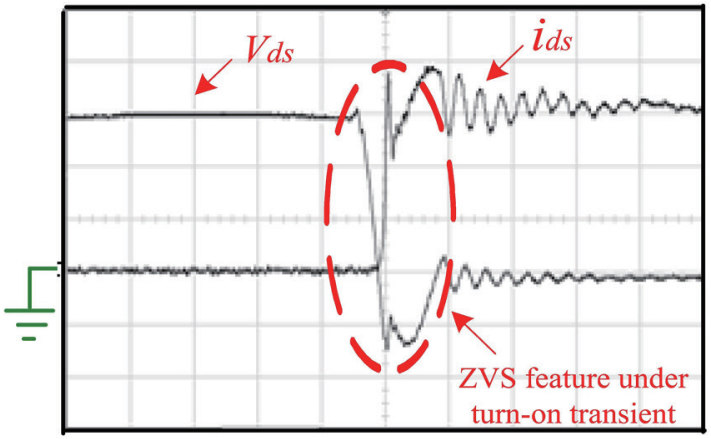

(a)

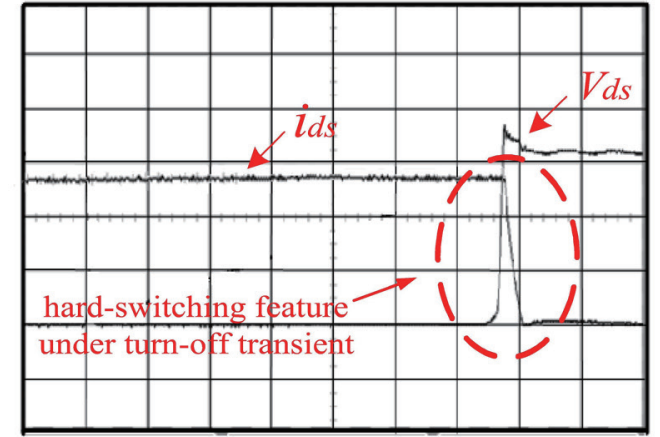

(b)

Fig. 8. (Color online) Measured voltage and current waveforms of main switch $\left(M_{a}\right)$ of the boost converter with a boost snubber: (a) operated at turn-on transient $\left(V_{d s(M a)}: 200 \mathrm{~V} / \mathrm{div}, i_{d s(M a)}: 1 \mathrm{~A} / \mathrm{div}\right.$, time: $\left.0.5 \mu \mathrm{s} / \mathrm{div}\right)$ and (b) operated at turn-off transient $\left(V_{d s(M a)}: 200 \mathrm{~V} / \mathrm{div}, i_{d s(M a)}: 1 \mathrm{~A} /\right.$ div, time: $\left.0.5 \mu \mathrm{s} / \mathrm{div}\right)$.

of the boost converter with a buck snubber. It can be seen that the main switch $\left(M_{a}\right)$ has a hardswitching feature at the turn-on transient and a ZVT switching feature at the turn-off transient. Figure 8 shows the voltage waveforms of the main switch $\left(M_{a}\right)$ of the boost converter with a boost snubber. It can be seen that the main switch $\left(M_{a}\right)$ has a ZVS feature at the turn-on transient and a hard-switching feature at the turn-off transient. Figure 9 shows the efficiency measurements of the boost converters with the three different snubbers, from which it can be seen that the boost converter with a boost snubber obtains the highest efficiency. This is because the main switch $\left(M_{a}\right)$ of the boost converters with an LCD snubber and with a buck snubber is operated with the same hard switching at the turn-on transient, resulting in high switching losses and high peak currents. The performances of the boost converters with the three different snubbers are summarized in Table 1. 


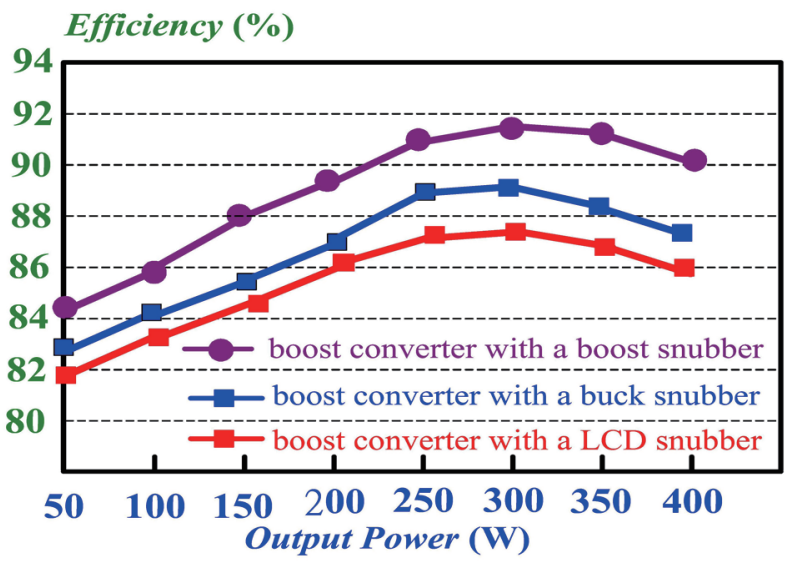

Fig. 9. (Color online) Efficiency of the proposed boost converters with three different snubbers under full-load condition.

Table 1

Comparison among the performances of the boost converters with three different snubbers.

\begin{tabular}{|c|c|c|c|}
\hline Performances & $\begin{array}{l}\text { Boost converter with an LCD } \\
\text { snubber }\end{array}$ & $\begin{array}{l}\text { Boost converter with a buck } \\
\text { snubber }\end{array}$ & $\begin{array}{l}\text { Boost converter with a boost } \\
\text { snubber }\end{array}$ \\
\hline Main switch $\left(M_{a}\right)$ & $\begin{array}{l}\text { - Hard switching } \\
\text { operated at turn-on } \\
\text { transient } \\
\text { - ZVT operated at turn-off } \\
\text { transient }\end{array}$ & $\begin{array}{l}\text { - Hard switching } \\
\text { operated at turn-on } \\
\text { transient } \\
\text { - ZVT operated at turn-off } \\
\text { transient }\end{array}$ & $\begin{array}{l}\text { - ZVS operated at turn-on } \\
\text { transient } \\
\text { - Hard switching operated at } \\
\text { turn-off transient }\end{array}$ \\
\hline $\begin{array}{l}\text { Component counts of } \\
\text { snubber }\end{array}$ & $\begin{array}{l}- \text { Inductor }=1 \\
- \text { Capacitor }=2 \\
\cdot \text { Diode }=3 \\
\text { - Active switch }=1\end{array}$ & $\begin{array}{l}- \text { Inductor }=2 \\
- \text { Capacitor }=2 \\
\cdot \text { Diode }=4 \\
\text { - Active switch = } 2\end{array}$ & $\begin{array}{l}- \text { Inductor }=2 \\
- \text { Capacitor }=2 \\
\cdot \text { Diode }=3 \\
\text { - Active switch }=2\end{array}$ \\
\hline Efficiency & $87 \%$ & $89 \%$ & $91 \%$ \\
\hline
\end{tabular}

\section{Conclusions}

In this paper, two different snubbers of a boost converter for achieving soft-switching features were compared. The performances of a traditional LCD snubber, a buck snubber, and a snubber incorporated in boost converters were compared. From the measured voltage and current waveforms of the boost converters with the LCD snubber, with the buck snubber and with the boost snubber, it can be seen that the boost converter with the boost snubber had the highest efficiency. This is because the main switch $\left(M_{a}\right)$ of the boost converter with the boost snubber had a ZVS feature operated at the turn-on transient. From the experimental results, it was confirmed that the efficiency of the boost converter with the boost snubber is greater than those of the boost converters with the other two snubbers.

\section{Acknowledgments}

This paper was supported by National Chin-Yi University of Technology, Taiwan. 


\section{Author Contributions}

All authors contributed to this paper. Cheng-Tao Tsai wrote the paper, Yan-Wei Huang contributed to the experimental results of the proposed circuits, and Tsair-Chun Liang proofread the paper.

\section{Conflicts of Interest}

The authors declare that there are no conflicts of interest regarding the publication of this paper.

\section{References}

1 K. J. Boelter and J. H. Davidson: Aero. Sci. Techno. 27 (1997) 689. https://doi.org/10.1080/02786829708965505

2 G. S. Peter Castle, I. I. Inculet, and K. I. Burgess: IEEE Trans. Ind. Gen. Appl. IGA-5 (1969) 489. https://doi. org/10.1109/TIGA.1969.4181060

3 A. Ajami, H. Ardi, and A. Farakhor: IEEE Trans. Power Electron. 30 (2015) 4255. https://doi.org/10.1109/ TPEL.2014.2360495

4 P. A. Lawless: Aero. Sci. 27 (1996) 491. https://doi.org/10.1016/0021-8502(95)00541-2

5 L. Liu, J. Guo, J. Li, and L. Sheng: J. Electron. 48 (2000) 81. https://doi.org/10.1016/S0304-3886(99)00049-2

6 H. Halbritter, C. Jager, R. Weber, M. Schwind, and F. Mollmer: IEEE Photo. Tech. Lett. 26 (2014) 1871. https:// doi.org/10.1109/LPT.2014.2336732

7 T. F. Wu, Y. D. Chang, C. H. Chang, and J. G. Yang: IEEE Trans. Power Electron. 27 (2012) 1108. https://doi. org/10.1109/TPEL.2011.2126024

8 S. Jung and G. H. Cho: IEEE Trans. Ind. Electron. 61 (2014) 6710. https://doi.org/10.1109/TIE.2014.2316221

9 A. S. Viner, P. A. Lawless, D. S. Ensor, and L. E. Sparks: IEEE Trans. Ind. Appl. 28 (1992) 504. https://doi. org/10.1109/28.137427

10 H. Wang, H. S. Chung, and A. Ioinovici: IEEE Trans. Power Electron. 27 (2012) 2242. https://doi.org/10.1109/ TPEL.2011. 2173588

11 C. T. Tsai, J. C. Su, and S. R. Wei: Sens. Mater. 31 (2019) 327. https://doi.org/10.18494/SAM.2019.2086

12 A. Ajami, H. Ardi, and A. Farakhor: IEEE Trans. Power Electron. 30 (2015) 4255. https://doi.org/10.1109/ TPEL.2014.2360495

13 M. L. T. Nadia, S. Inoue, A. Kobayashi, and H. Akagi: IEEE Trans. Power Electron. 23 (2008) 2755. https://doi. org/10.1109/TPEL.2008.2005388

14 H. M. Sizkoohi, J. Milimonfared, M. Taheri, and S. Salehi: IET Trans. Power Electron. 8 (2015) 1786. https:// doi.org/10.1016/j.apenergy.2016.12.094

15 T. F. Wu, Y. D. Chang, C. H. Chang, H. X. Lee, K.-Y. Lee and J.-G. Yang: 2009 Inter. Conf. Power Electron. and Drive Syst. (PEDS, 2009) 187. https://doi.org/10.1109/PEDS.2009.5385795

16 T. J. Liang and J. H. Lee: IEEE Trans. Ind. Electron. 62 (2015) 4492. https://doi.org/10.1109/TIE.2014.2386284

17 S. Y. Tseng and C. T. Tsai: Int. J. Photoenergy 2012 (2012) 1. https://doi.org/10.1155/2012/936843

18 S. W. Lee and H. L. Do: IEEE Trans. Power Electron. 32 (2017) 1375. https://doi.org/10.1109/ TPEL.2016.2549029

19 T. F. Wu, Y. D. Chang, C. H. Chang, and J. G. Yang: IEEE Trans. Power Electron. 27 (2012) 1108. https://doi. org/10.1109/TPEL.2011.2126024

20 Y. M. Chen, S. Y. Tseng, C. T. Tsai, and T. F. Wu: IEEE Trans. Aero. Electron. Syst. 40 (2004) 954. https://doi. org/10.1109/TAES.2004.1337467 